\title{
The Rationale for the Duty to Consult Indigenous Peoples: Comparative Reflections from Nordic and Canadian Legal Contexts
}

\author{
Christina Allard*
}

\author{
Luleå University of Technology, Division of Social Sciences / Law, Sweden, and UiT - The \\ Arctic University of Norway
}

\begin{abstract}
Although the standard of consulting Indigenous peoples in decisions affecting them is well rooted internationally as well as in national legal systems, different views and patterns of problems are associated with the concept and its practice. This paper briefly analyses and contrasts the duty to consult Indigenous peoples through a comparison of the three Nordic countries Norway, Finland and Sweden, and Canada. Based on domestic legal sources, the focus of the paper is to explore the legal foundation that has given rise to the specific set of rules for the duty to consult, that is, the rationale behind the evolving of the rules. The first finding is that the rules differ among the three Nordic countries, with Sweden being the only country that lacks specific rules. Secondly, whereas Canada has developed its own duty to consult primarily through domestic case law, in the Nordic countries, duty to consult is related to international law obligations. Consultation duties that have evolved from domestic law may be easier to accept than "foreign" regulations imposed on national legal systems. This could explain the reluctance among the Nordic States to accept specific consultations with the Sami Parliament and other Sami groups, particularly in Sweden.
\end{abstract}

Keywords: consultation; participation; Indigenous rights; Sami rights; Aboriginal rights; Nordic law; Canadian law

Responsible Editor: Hans-Kristian Hernes, UiT - The Arctic University of Norway, Tromsø, Norway.

Received: April 2017; Accepted: October 2017; Published: February 2018

^Correspondence to: Christina Allard, christina.allard@ltu.se 


\section{Christina Allard}

\section{Introduction}

Consultation is an increasingly important aspect of Indigenous people's law, including in the Arctic region, ${ }^{1}$ its purpose being to engage in good faith and reach unanimity and understanding. Rules concerning consultation are designed to build dialogue; it is expected that the State and affected Indigenous people try to reaching a mutually satisfactory agreement in earnest. However, there is no specific formula for consultation that works in all circumstances and across all jurisdictions, rather, its practice tends to be country specific notwithstanding international attention on the matter. ${ }^{2}$ With respect to the procedural side of Indigenous rights, consultation of indigenous groups by a State can be seen as a key element in ensuring successful melding between groups in bi- or multi-cultural societies. Consultation and participation are understood to form the cornerstone of the ILO Convention Concerning Indigenous and Tribal Peoples in Independent Countries, 1989 (hereinafter ILO Convention No. 169) and the basis for applying other articles. ${ }^{3}$ Participatory rights have also been strongly promoted in the UN Declaration on the Rights of Indigenous Peoples (UNDRIP), 2007, especially the concept of free, prior and informed consent (FPIC) of Indigenous peoples. ${ }^{4}$

Today there are many international documents that secure participatory rights for Indigenous peoples, among which Articles 6 and 7 of ILO Convention No. 169, which are legally binding to its parties, figure prominently. Consultations do not, however, allow for "veto power" over developments, ${ }^{5}$ nor do they hold any promise that matters pivotal to the Indigenous community will be accommodated and adopted. It has been argued that consultation as a procedure is not meant to constitute an effective veto. ${ }^{6}$

The law, nevertheless, is evolving, both in the international and domestic spheres. It should be noted that, in line with UNDRIP, there is presently a shift from consultation to consent in international law, an issue that will not be addressed here. The basic idea of FPIC is rather straightforward, but legally it is a contested and confused concept. ${ }^{7}$ Whereas FPIC should be understood as an extension of already established international standards regarding the participatory and consultation rights of Indigenous peoples, ${ }^{8}$ legislators and courts in the countries included in this study have thus far not paid much attention to the concept. Notably, Canada first voted against the adoption of UNDRIP, primarily because of FPIC, but has recently started addressing and discussing implementation of UNDRIP as a means for transformative change in state-Indigenous relationships (see Ch. 4). Even though domestic courts have made general references to the Declaration, for instance, regarding its usefulness as an interpretive aid to Canadian legislation, courts have thus far been reluctant to rely explicitly on the FPIC standard..$^{9}$

Hence, this article seeks first to analyse and contrast approaches to the duty to consult Indigenous peoples in the Nordic countries, Norway, Finland and Sweden, and then contrasts the different rationales for consultation with Canadian law and practice concerning the duty to consult. In doing so, this paper describes the legal 
basis for consultations in the respective jurisdictions by analysing national law, preparatory works and relevant case law. With respect to Swedish law, the paper also provides a timely example of corporate consultations in mining situations, revealing problematic aspects for Sami reindeer-herding communities.

\section{The Nordic Legal Context and Constitutional Protection of Sami Culture}

This section provides relevant insights into the Nordic legal context in order to facilitate an understanding of the subsequent analysis of Nordic law. Of fundamental importance is how claims for Sami rights in the Nordic countries have generally been channelled through public government commissions that investigate and recommend legal amendments. Commission reports form part of the preparatory works for a statute, themselves an important source of law in interpreting the content of legislation. In contrast to Canada, case law claims for Sami rights are rather limited, especially in Finland and Sweden, ${ }^{10}$ where civil law jurisdictions do not have the same tradition of filing lawsuits to solve disputes. ${ }^{11}$

There are no Sami reserve lands or title lands, equivalent to those established in Canada, nor any historical treaties with the Sami. Collective Sami ownership is not recognised, but strong user rights for reindeer-herding Sami, the reindeer-herding right, is. ${ }^{12}$ In 2001 the Norwegian Supreme Court, however, upheld collective ownership of a limited area by a local community with a Sami majority population (the Svartskogen case). ${ }^{13}$

On the whole, it has been difficult for the three states to acknowledge the legacy of their colonization of traditional Sami areas, although, by ratifying ILO Convention No. 169 in 1990, Norway has taken promising steps towards reassessing its relationship with the Sami as a people. It should be mentioned that Norwegian ratification of ILO Convention No. 169 coincided with several other developments in Norway, in particular (1) the adoption of a specific Sami Act in 1987, aimed at promoting Sami languages, culture and way of life, which included the establishment of a national Sámediggi (Sami Parliament), and (2) a new Sami clause in the Constitution (now section 108) in 1988, which addresses State obligations to safeguard and develop the Sami language, culture and way of life. After years of investigations and a bill, Finland is again considering ratification of ILO Convention No. 169, whereas the prospect of Sweden ratifying the Convention is unforeseeable.

The three countries are currently in the process of adopting a Nordic Sami Convention, based on relevant Human Rights treaties and to some extent aligned with UNDRIP. ${ }^{14}$ It guarantees minimum rights for the Sami (Article 2) across all relevant sectors and aims at harmonizing national rules in the long term. The objective of the Convention (Article 1) is to affirm and strengthen the rights of the Sami people to promote their language, culture and society with the smallest possible interference from national borders. The text also strengthens participatory rights, especially for the Sami Parliaments in Norway, Sweden and Finland (Articles 4, 17-18). ${ }^{15}$ Article 17 also says that prior decisions, "consent", from the Sami Parliament shall be 


\section{Christina Allard}

pursued. It should be noted here that the Sami Parliaments in Norway, Sweden and Finland, named Sámediggi in the Sami language, lack any law-making powers and function quite differently comparatively. ${ }^{16}$ Although the Sámediggi do function as the most important representative body for the Sami as a people, they are by no means to be confused with real "parliaments".

Constitutional protection of Sami culture also differs between the three States. Comparatively, Norway and Finland offer better constitutional protection of Sami culture and livelihoods, even though provisions are seldom applied. ${ }^{17}$ The purpose behind the Norwegian provisions was explicitly to redress past grievances and assimilation policies towards the Sami. ${ }^{18}$ The provision in the Swedish constitution, called the Instrument of Government, does not create any enforceable rights for the Sami. ${ }^{19}$ After an important amendment in 2010, it now states that " $[t]$ he opportunities of the Sami people (...) to preserve and develop a cultural and social life of their own shall be promoted". Enforceable rights instead appear in Chapter 2 of the Act. None of the three State's constitutional provisions impose the duty to consult the Sami.

\section{The States' Consultation Duty in the Three Nordic States}

The duty on the states to consult the Sami was not on the public agenda before the focus on consultations in international law increased. ILO Convention No. 169 has been instrumental for developing such standards in Norway and Finland. Specific provisions that relate to the Sami as an Indigenous people, holding specific rights to be consulted by the State, did not come about until 1995 in Finland and 2005 in Norway. Sweden still lacks specific legislation, but a law-proposal has just been released, and is currently under hearing before it may be furthered into a bill. There is no independent case law on the matter. Consequently, among the Nordic countries it is clear that the states' duty to consult the Sami is considered an obligation under international law stemming from various Human Rights' Conventions.

\subsection{Two Consultation Agreements in Norway}

The legal basis for the duty to consult the Sami in Norway lies in two consultation agreements. A basic Consultation Agreement, in translation "Procedures for Consultations between State Authorities and the Sami Parliament", ${ }^{20}$ was signed in May 2005 between the Ministry of Local Government and Modernisation and the Sami Parliament. The Sami Parliament formally accepted the Agreement the following month. Thereafter it was extended to the whole of the Norwegian Government, including regional governments and state enterprises, through Royal Decree. A second specific agreement was negotiated concerning consultation on nature conservation matters in traditional Sami areas, here called the Consultation Agreement on Conservation, ${ }^{21}$ between the Ministry of Environment and the Sami Parliament in January 2007.

The story behind the development of an agreement concerning consultations is linked to the drafting of the Finnmark Act, an Act that established a new management system 
for land and natural resources in Finnmark, the northernmost county of Norway and a significant Sami area. During the law-making process, the Parliament's law committee undertook four meetings with the Sami Parliament and the Finnmark County Council on the draft legal text of the Act, resulting in substantial amendments to the legal text. Turning those initial meetings into a formal agreement was nevertheless a response to ILO Convention No. 169 Articles 6, 7 and 15, as well as indirectly Article 27 of the International Covenant on Civil and Political Rights, 1966 (ICCPR). ${ }^{22}$

This basic Consultation Agreement is the single most important undertaking for Sami rights in Norway, in that it gives the Sami the right to participate and influence decision-making at all stages where Sami interests and cultures are directly affected. ${ }^{23}$ The Agreement makes it difficult to disregard Sami customs, customary law and other cultural aspects since the Sami Parliament, or other Sami groups, must be consulted beforehand. Indeed the Agreement has meant that the Sami have had a substantial influence on, for instance, the drafting of new legislation such as the Finnmark Act, 2005, the Reindeer Herding Act, 2007, the Planning and Building Act, 2008 and the Nature Diversity Act, 2009.

The basic Consultation Agreement has nine articles, covering everything from the objective and scope of the Agreement to how consultation procedures should be carried out. Guidelines to the basic Consultation Agreement, issued by the Ministry of Labour and Social Affairs in 2006, aid interpretation of the Agreement and the state's consultation duty.

Behind the state's consultation duty, explicitly stated in both Consultation Agreements and the Guidelines, is the Sami's status as an Indigenous people and their right to be consulted in matters directly affecting them. The agreement is seen as a practical means to implement Norway's obligations under international law. Article 6 of ILO Convention No. 169 is referred to in particular. ${ }^{24}$ Consultations shall be undertaken in good faith and with the aim of reaching unanimity or consent. ${ }^{25}$ Moreover, these consultations should also facilitate the sense of partnership between state authorities and the Sami Parliament (article 1). However, there is a reminder that the state always has the final say and legal competence in any matter. ${ }^{26}$

Who are the subjects of the Consultation Agreement? From the basic Consultation Agreement it is clear that not only is the Norwegian Government bound by the Agreement, but "state authorities", meaning - apart from the Government and its ministries - directorates and other subordinate state agencies, such as regional governments (i.e. county councils) and state enterprises in as much as they exercise public authority. ${ }^{27}$ In particular, it is the state authority that holds the decision-making power that is bound by the consultation duty, but in certain instances this duty may also apply to subordinate authorities, such as regional governments, which may have the responsibility of investigating certain matters prior to decisions. ${ }^{28}$ Municipalities, which have considerable governmental powers on the local level, are, however, not included. ${ }^{29}$ The reason for this omission is that the Government wanted to investigate further how municipal decision-making could be included in an expedient way. 


\section{Christina Allard}

With regard to the Sami, the Sami Parliament, which serves as a representative for all the different Sami interests, is the key beneficiary of the Agreement. Under circumstances where there is a local effect on the Sami, other Sami organisations may also be subject to the Agreement. ${ }^{30}$

Sami reindeer-herding representatives have a special position here; reindeer herders have their own branch organization and a tradition of representing their own interests. The emphasis in Article 6.1(a) of ILO Convention No. 169, in particular the wording "the peoples concerned", and the Guidelines to the basic Consultation Agreement from 2006 acknowledges that Norway does not fulfil its obligations if consultation is limited to the Sami Parliament. Consequently, in addition to the duty to consult the Sami Parliament, state authorities may also need to consult other Sami groups, in particular concerning matters that apply to traditional Sami industries.

Whether the state authorities should consult with Sami organisations or individual right-bearers depends on the matter at hand. ${ }^{31}$ For instance, legislative proposals or other matters of general interest are more likely to concern broader local Sami organisations and specific branch organisations, whereas single administrative measures, such as environmental/natural resource planning, and procedures concerning permits related to land use and exploitation, often involve a potential infringement on reindeer-herding rights. Even Swedish reindeer-herding communities with transnational reindeer-herding rights in Norway must occasionally be consulted if their interests are directly affected.

This leads us to the scope of consultation. The basic Consultation Agreement applies equally to "legislative or administrative measures that may directly affect Sami interests" (article 1). In other words, it is wide-ranging and includes all material and immaterial forms of Sami culture (article 2). It relates, for example, to issues of cultural heritage, religion, language, traditional knowledge, land ownership and user rights as well as competing land utilization in larger planning and licensing processes, apart from law drafting. ${ }^{32}$ Consultation encompasses all forms of Sami culture, such as cultural heritage, property rights, land administration, nature conservation, traditional knowledge, music, education, health and social welfare. The geographical scope of the Agreement is limited to "traditional Sami areas" in matters concerning land administration, competing land utilization and land rights (article 2). Although this area is difficult to demark, it encompasses in principle the lands where reindeer herding is carried out today, comprising about 40 percent of the Norwegian territory. ${ }^{33}$ Importantly, all other general matters apply equally across Norway.

Deviation from the procedures in the basic Consultation Agreement may be allowed if the parties agree on other provisions for certain areas of affairs. ${ }^{34}$ The abovementioned Consultation Agreement on Conservation from 2007 is an example of this, with its more specific procedures related to protected area designation and management. The provisions focus on consultations concerning nature conservation plan processes on the local, regional and national levels. ${ }^{35}$ The Agreement includes 
six articles and explicitly mentions "the Sami Parliament/Sami organizations/Sami right-bearers" as the beneficiaries (for example in article 1). Its scope is limited to "traditional Sami areas" (article 2). Competent state authorities are regional governments, the Norwegian Environment Agency and Ministry for the Environment (article 5).

All in all, the two Agreements are wide-ranging and make it possible for the Sami Parliament and local Sami who are affected to have a real influence both on decision-making and objectives. Being political agreements, alleged breaches of the duty to consult the Sami are difficult to enforce nationally. ${ }^{36}$ Such matters may only be brought to light in connection with, for instance, the ILO's report and complaint procedures. There is, however, a proposal from the Sami Rights Committee from 2007 for a new act to include the state's consultation duties towards the Sami. ${ }^{37}$ It has not yet become a bill, but consultation with the Sami Parliament is currently underway. It is also worth mentioning that several consultation agreements have been negotiated between regional governments (within traditional Sami areas) and the Sami Parliament, such as the Troms, Nordland and Hedmark counties. As such, these agreements focus more on language, art, music, theater, sports, etc. than the use of land and resources, but nonetheless they are an important acknowledgement that the Sami Parliament has a role in Norwegian public administration. ${ }^{38}$

\subsection{Statutory Recognition of Consultation in Finland}

In Finland, the state's statute-based consultation duty towards the Sami is presently limited geographically to an administratively demarked area in the Finnish far north, "the Sami homeland". ${ }^{39}$ Within this specific area the Finnish Constitution from 1999 grants the Sami linguistic and cultural self-government, ${ }^{40}$ which is related to the Sami as an Indigenous people and which is also reiterated in section 1 of the Sami Parliament Act, 1995. A provision stating the duty to consult the Sami is included in this Act (section 9).

Finland's ambition was to become party to ILO Convention No. 169 and a bill had even been drafted recommending ratification of the Convention, but it was unexpectedly tabled by Parliament in spring 2015. ${ }^{41}$ Another bill aimed at reforming and updating the Sami Parliament Act, including an amended provision concerning consultation, was also postponed..$^{42}$ Of relevance here is the suggestion that consultation should be expanded beyond the Sami homeland and also be binding on regional and local authorities. Despite setbacks, the Finnish Government still aims to strengthen the consultation rights of the Sami by revising the consultation provision in the Sami Parliament Act, 1995, and the Ministry of Justice is currently preparing guidelines regarding consultations applicable for state officials.

Section 9 of the current Sami Parliament Act uses the wording "negotiate" (förhandla), but it is clear that the purpose behind the provision is the equivalent of consultation. Evidently, the Finnish language lacks the term "consult", therefore the closest term "negotiate" was chosen. The provision states that "[ $\mathrm{t}]$ he authorities 


\section{Christina Allard}

shall negotiate with the Sami Parliament in all far-reaching and important measures which may directly and in a specific way affect the status of the Sami as an indigenous people". The term "authorities" is not defined in the Act, but in preparatory works it is said to include Ministries and state authorities responsible for public administration tasks. ${ }^{43}$

The scope for consultation is exemplified in section 9 in five specific areas: i) community planning, ii) land management and protected areas, iii) exploration and extraction of minerals on state-owned lands, iv) amendments in legislation or public policy related to Sami livelihoods, and v) Sami education and social and health care. A sixth area mentioned in the provision is a catch-all because it relates to other measures that affect Sami language, culture or status as an Indigenous people. An important amendment was made in 2011, aimed at aligning Finnish legislation with the requirements of ILO Convention No. 169, when mineral exploration and extraction on state-owned lands was included in the consultation duty.

As mentioned above, consultations are restricted to the confined area of the Sami homeland. This area encompasses some ten percent of Finnish territory, 90 percent of which is state-owned land. ${ }^{44}$ The demarcation of the area is contested, with some scholars claiming that the traditional Sami area is in fact larger..$^{45}$ Another limitation of Finland's consultation provision is that the beneficiary is limited to the Sami Parliament; local Sami groups, such as reindeer-herders, are not affected. One reason for this exclusion may be that the Sami do not officially have a specific reindeer-herding right in accordance with reindeer-herding legislation, nor is reindeer herding an exclusive Sami occupation in Finland. ${ }^{46}$ Moreover, the Skolt Sami, a Sami sub-group living in the northeast corner of Finland, are the subject of a specific Skolt Act, 1995, which does not give them independent consultation rights with the Finnish State. ${ }^{47}$

The Sami Parliament, according to section 6 of the Sami Parliament Act, is the body meant to represent the Finnish Sami in national and international matters. Therefore, in some instances and according to other legislation, the Sami Parliament is given the opportunity to comment on legislative proposals (remiss), to be heard, and to make observations.$^{48}$ These are, however, common administrative procedures that also apply to other interests groups. Swedish law has similar rules, which will be briefly addressed below.

\subsection{Lack of State Obligations Concerning Consultation in Swedish Law}

In contrast to Norway and Finland, Sweden does not have an agreement or a piece of legislation in place yet which includes specific consultation duties towards the Sami. A first proposal in 2009 to implement such a provision was not successful because other parts of the proposal were heavily criticised by the Sami Parliament and legal scholars, eventually halting formulation of a bill..$^{49} \mathrm{~A}$ second proposal suggesting the enactment of a specific Act on consultations with the Sami Parliament was released in late September $2017 .^{50}$ It is likely that this legislation will be passed, not least because of the pending Nordic Sami Convention that stipulates consultation duties with the Sami. 
I will now turn briefly to the two legal proposals. The reason behind the 2009 proposal was international criticism of Sweden by several international human rights' bodies. The report concluded that this implies that the Sami as an Indigenous people may have special status in relation to other ethnic groups. ${ }^{51}$ Ironically, no prior consultations were held with the Sami Parliament regarding this proposed provision. This reluctance to consult is also revealed by the status of the proposed consultation provision, which was to be included in subordinate legislation in a regulation with instructions to the Government Offices/Ministries, and in detailed provisions by decree (arbetsordning). The legal status of a regulation is below that of an act in cases of inconsistency. A decree has even lower legal status. In this way, the regulation was not complicated by the creation of specific constitutional rights for the Sami. ${ }^{52}$ Moreover, this provision was limited to consultations between the Ministries and the Sami Parliament in law-making matters. ${ }^{53}$

Instead, the recent legal proposal suggests a new act on consultation with nine sections, drafted with inspiration from the Norwegian consultation model, the Nordic Sami Convention and recommendations from international human rights' monitoring bodies. ${ }^{54}$ It is clear from the proposal that the level of ambition has increased substantially. On the whole the law-proposal is well-balanced. Consultations are to be conducted not only with the Sami Parliament, but also with other Sami organisations and/or Sami reindeer herding communities if they are particularly affected by a decision. Moreover, the act has no geographical limitation, unlike the Finnish provision. The consultation duty of the State is proposed to include the Swedish government, public authorities, county councils and municipalities. Furthermore, consultations are to be conducted in good spirit with parties actively seeking agreement or consent on matters.

Though it currently lacks an explicit consultation right, the Swedish Sami Parliament is not entirely devoid of influence. As in Finland, the Swedish Sami Parliament has functions related to public administration, specifically commenting on legal proposals and other matters sent to them from the Government and other state authorities (remisser). In contrast to the Sami Parliaments in Norway and Finland, their Swedish counterpart is paradoxically both an elected assembly and a public authority under the jurisdiction of the Swedish Government. ${ }^{55}$ Under the Sami Parliament Act, 1992, the Sami Parliament as a public authority is, among other things, tasked with cooperating in community planning, and monitoring that Sami interests are taken into account, especially with respect to reindeer husbandry. The Sami Parliament has additional tasks under other legislation..$^{56}$

For instance, the Government is obligated under the Swedish Constitution, the Instrument of Government from 1974, to obtain information and opinions (yttranden) from competent public authorities when preparing government matters. ${ }^{57}$ The Public Administration Act, 1986, also has provisions aimed at facilitating cooperation among public authorities. ${ }^{58}$ In addition, there is a provision aimed at minorities in Sweden that applies to the Sami in general and not only the Sami Parliament. 


\section{Christina Allard}

The Act on National Minorities and Minority Languages, 2009, section 5, states that public authorities must give national minorities the chance to influence matters that concern them, and, as far as is feasible, consult (samråda) with representatives for the minorities. This provision is rather ambiguous and designates the Sami as a national minority.

If the proposed act on consultation becomes a reality, it will mean something entirely different. It will allow the Sami Parliament, other Sami organisations and affected reindeer herding communities to have a stronger influence in matters pertaining to the Sami people and their own future. The question remains, however, why has Sweden lagged behind Norway and Finland?

Previous research has shown that public policy in Sweden has treated the Sami more as a "national minority" rather than as an autonomous Indigenous people..$^{59}$ The notion of building partnerships, explicit for instance in the Norwegian Consultation Agreement (article 1), is non-existent in the public State-Sami relationship. Nor is the idea of a nation-to-nation approach as a means to promote reconciliation part of the public vocabulary or rhetoric, as it is, for instance, in Canada. Until the revision of the Swedish Constitution in 2010, the Sami were still mentioned as a minority (cf. above Ch. 2). This has had implications for the Sami rights discourse in Sweden, including the state's duty to consult. ${ }^{60}$

\subsubsection{Corporate Consultations in Swedish Mineral Exploitations}

Consultation with the Sami in the context of mining offers a timely example of a global situation where the need for minerals is steadily increasing, and the majority of mining permit applications in Sweden pertain to Sami reindeer herding areas. At the same time, it reveals the shortcomings of Swedish legislation regarding the absence of state consultation with the Sami, with potentially far-reaching consequences for the future of reindeer herding in the communities where exploration permits have been granted and potential mines may be established. Mineral exploitation in the Swedish north has garnered recent national and international attention following protest movements by Sami groups, environmental organisations and individuals, especially with respect to a planned mine outside Jokkmokk in Kallak/Gállok. ${ }^{61}$

Consultation with the Sami in a Swedish legal context means corporate consultation with affected reindeer-herding communities. It is important to note that this form of consultation is not equivalent to the duty to consult Indigenous peoples since it does not involve the state or stem from the Sami as an Indigenous people. In Sweden this form of consultation is called samråd and is widespread in for instance natural resources statutes related to the consideration of and balance between right-holders or other interested parties. In such cases, the state has no particular responsibility or role towards the Sami as an Indigenous people.

A common form of corporate consultation is related to the environmental impact assessment (EIA). The core environmental statute, the Environmental Code of 1998 
encompasses rules on EIA for projects in Chapter 6, which many other Acts in the environmental/natural resources area refer to, including the Minerals Act, 1991. With respect to the EIA, an affected reindeer-herding community is treated like any other stakeholder, even when traditional Sami lands are impacted. Moreover, consultation does not necessarily involve all aspects relevant to an affected reindeer-herding community, because its main target is the environmental impact of a project, and not how development may affect the reindeer-herding right as a property right or other social/ cultural factors. ${ }^{62}$

The Minerals Act, written to promote exploitation of Sweden's mineral resources, makes few requirements on mining companies to carry out samråd. In fact, an exploration permit can be issued by the competent authority, the Mining Inspectorate of Sweden, without consulting affected reindeer-herding communities, or even property owners for that matter. ${ }^{63}$ With respect to the EIA, there is no requirement for mandatory stakeholder consultation, although consultation is normally carried out voluntarily by applicants. ${ }^{64}$ Notably, this practice reveals a gap between written law and what companies feel obliged to do. The same applies to the EIA report, where a so-called reindeer-herding impact assessment (rennäringsanalys) is usually made nowadays.

Amendments made in 2014 in relation to exploration permits, increase information flow and dialogue in the early stages of development between a company and stakeholders, especially targeting the Sami and other national minorities ${ }^{65}$ A work plan (arbetsplan) must be approved before any exploration is carried out, in accordance with the exploration permit. ${ }^{66}$ An affected reindeer-herding community, among other stakeholders, must be informed of this work plan and the community may respond in writing. In the event that a company and reindeer-herding community cannot reach agreement, the Chief Mining Inspector may authorise the work plan if it meets statutory requirements regarding content. A reindeer-herding community may request that the work plan be translated into the Sami language.

In addition, environmental permits are required under the Environmental Code in order to run a mine and its related activities. ${ }^{67}$ Here the Sami and other affected stakeholders are consulted in the context of the EIA. This late in the process, a Sami community may only stress the need for mitigation, since the exploitation permit under the Minerals Act has already been granted.

To sum up, Swedish mineral legislation lacks a consultation requirement that would give the Sami the possibility of exercising a real influence on the process and outcome. As long as consultation merely means corporate consultation, samråd, the Sami have little influence over resource exploitation, which may potentially have a severe impact on a community's reindeer herding activities. Although proper consultations with the state would not allow vetoing of mineral exploitation, nevertheless on a strategic level, future legislation may be informed by a better balance between the interests of mineral development and those of conserving an Indigenous livelihood that is the cornerstone of Sami culture. 


\section{Christina Allard}

\subsection{Short Comments}

Although the consultation duty of the three Nordic States towards the Sami is rationalised on the basis of international law obligations (Human Rights treaties), the countries exhibit highly diverse interpretations of this duty.

The two Consultation Agreements in Norway have a broader scope than the provision in the Finnish Sami Parliament Act, 1995. Though the consultation provision in Finland was novel at the time of its incorporation, it has taken a long time to establish firm grounds for consultation, and still seems to lack the effectiveness that the consultation arrangement enjoys in Norway. One reason may, in fact, be the tight economic situation of the Finnish Sami Parliament, which has the fewest allocated resources between the three. ${ }^{68}$ In fact, the Norwegian Sami Parliament is the most powerful of the three because it has continuously increased its autonomy and influence. ${ }^{69}$ Another factor may be Norway's progress in addressing State-Sami relations since the end of the 1980s and onwards, acknowledging past wrongs and showing a willingness to build a new partnership with the Sami. Despite internal criticism from the Sami, ${ }^{70}$ and room for improvement, consultation, in comparison, functions rather well in Norway and has on several accounts been successful, not least in relation to law-making processes.

As indicated, the State's consultation duty in Norway encompasses the whole country in general matters and the vast reindeer herding area in matters pertaining to land management (traditional Sami areas), whereas, so far, the Finnish section 9 is confined to the Sami homeland area. Notice that the majority of the Sami in all three countries live in urban areas outside the traditional Sami region. The Finnish provision is also limited with respect to whom the Finnish Sami Parliament may consult with, that is, the Government and state authorities, while in Norway, regional governments and state enterprises may in certain instances also have consultation obligations, however, the question of how to include municipalities has still not been solved. Other Sami groups in Norway also have the right to be consulted when necessary, which is especially relevant in resource development projects such as mineral extractions. Otherwise, matters subject to consultation are more or less the same in both countries.

Presently Sweden lacks any specific formal or non-formal rules on consultation with the Sami, but a legal proposal has recently been forwarded (see Ch. 3.3). Consultations, or rather samråd, are conducted in the EIA process as corporate consultations. These consultations are restricted to environmental matters, which were deemed to be insufficient in the recent Canadian Clyde River case (see below Ch. 4). On the whole, Sweden has problems in addressing the Sami as a distinct (Indigenous) people, despite a prominent international reputation otherwise in upholding and promoting human rights.

All three Nordic countries apply a dualistic approach towards international law. Although Sweden and Finland have ratified all major Human Rights Conventions, they have explicitly only incorporated the European Convention on Human Rights. ${ }^{71}$ 
In Norway international law, comparatively, seems to play a more prominent role, evident for instance in Government Commissions (preparatory works) where international obligations are closely and lengthily evaluated, at least in matters pertaining to environmental protection and Sami rights issues. Norway directly incorporated five major Human Rights Conventions into their domestic laws in $1999^{72}$ (but not the ILO Convention No. 169). Where there is an inconsistency with domestic law, provisions in the Convention trump. Norway is already a party to ILO Convention No. 169 and has a legal obligation to conform to it. Consequently, these Human Rights treaties have a stronger position in the Norwegian legal culture, which is supportive of Sami rights discourse.

Norway, Finland and Sweden have traditionally relied on international laws and obligations regarding their duty to consult the Sami in matters directly affecting them. This approach contrasts with Canada, where the duty to consult is incorporated into national legislation. It has taken longer for the Nordic countries to discuss and properly acknowledge consultations vis-à-vis the Sami compared to the Canadian approach to this duty. One explanation for this may be that international law is seen as "foreign" until properly incorporated into national legal systems, and therefore barristers and courts in the Nordic countries have refrained from acknowledging and applying international consultation standards with respect to the Sami.

\section{The Duty to Consult in Canadian Law}

Interestingly, in the Canadian legal context the state's duty to consult is not informed by international law obligations, but is seen first and foremost as a basic constitutional right. It is associated with impacts on Aboriginal claims and rights, including prima facie rights. ${ }^{73}$ The state's obligation to consult has evolved through case law under section 35(1) of the Constitution Act, 1982, and thereby offers special protection for Aboriginal and treaty rights. Section 35(1) declares that "[t]he existing aboriginal and treaty rights of the aboriginal peoples of Canada are hereby recognized and affirmed". Early case law confirms that this short provision provides a constitutional base upon which subsequent negotiations can take place. ${ }^{74}$ Notice that specific rules on consultation are part of modern land claims agreements, which include the Canadian Arctic, an issue that is not addressed in this paper. ${ }^{75}$

The early jurisprudence on the state's consultation duty has evolved under the principle of the honour of the Crown, ${ }^{76}$ meaning the duty of dealing honourably with matters arising from an assertion of sovereignty. The principle is of great relevance, especially in Crown dealings related to land and natural resources and potential impacts on Aboriginal communities' rights. ${ }^{77}$ The Haida Nation case was the first Supreme Court case to address consultation and concerned logging on islands to which a tribe has claimed title for over a hundred years. The Court held that the Province had failed to meet its consultation duty and that this duty also required accommodating the interests of the tribe. ${ }^{78}$ 


\section{Christina Allard}

Several succeeding cases, from 2010 and onwards, have developed the content and circumstances of the duty to consult. For instance, the recent Clyde River case (July 2017) concerned whether a federal independent agency, the National Energy Board (NEB), had fulfilled the Crown's consultation obligation..$^{79}$ The NEB, which in this case approved offshore seismic testing for oil and gas in Nunavut that could negatively affect the treaty rights of the Inuit of Clyde River, was acting on behalf of the Crown when it as the final decision maker authorized the project application. The company had consulted with the Inuit group and the group had (limited) opportunity to participate in the NEB's process. But, as the discussion concerning affected aboriginal rights was subsumed within an environmental assessment, consultation and accommodation were held to be inadequate and fell short in several respects, not least in the failure to inquire into the impact on the right itself, not only the environmental effects per se. As a result NEB's authorization was quashed by the Supreme Court of Canada.

Nowadays there are detailed government policies on the duty to consult at provincial and federal levels, and some Aboriginal communities have developed their own policies. ${ }^{80} \mathrm{~A}$ few provinces have included consultation requirements in natural resources law, such as mining legislation.

An interesting development worth mentioning here has occurred with respect to the ten principles adopted by the Government of Canada summer 2017, "Principles respecting the Government of Canada's relationship with Indigenous peoples", and that may affect the application of the Crown's consultation duty in the near future..$^{81}$ The Principles are an attempt at renewing the Crown-Aboriginal relationship, and among other things it is stated that UNDRIP requires transformative change with respect to this relationship. Principle six mentions that this renewed relationship should go beyond the legal duty to consult, and refers explicitly to the concept of FPIC, stating that this standard to secure consent will be strongest concerning Aboriginal title lands. Hence, UNDRIP and the concept of FPIC may very well become influential in the near future, at least in policy regarding the consultation and accommodation duties of the Canadian State.

Briefly, the duty to consult primarily belongs to governments, but can be delegated to third parties, normally in relation to an EIA..$^{82}$ Nevertheless, ultimate responsibility for the duty rests on the Crown alone, although it is becoming more common for industry stakeholders and Aboriginal communities to engage in corporate consultation and in fact make it a non-optional practice. ${ }^{83}$ Beneficiaries of the duty are rights-bearing Aboriginal communities under section 35 of the Constitution. Government measures affecting Aboriginal communities' land and resource rights is the chief focus of consultation. Whether the duty to consult includes legislative actions has not yet been decided by case law, but was briefly raised in one case from $2010^{84}$, and might become common practise because of the Principles mentioned above. ${ }^{85}$ The content of the consultation and accommodation varies with the validity of the claim and the seriousness of the effect on the asserted right (a spectrum approach) ${ }^{86}$ Within this spectrum, the duty ranges from minimal notice to substantial 
consultation and accommodation, but does not presently include a power of veto for the Aboriginal community. ${ }^{87}$ The duty to consult has gained prominence in the field of Aboriginal law in Canada, but it is a complex doctrine and continues to evolve both within and outside the law.

\section{Short Conclusions}

A common denominator among the Nordic countries is an understanding that the duty to consult the Sami stems from obligations under international law and various treaties, which in turn leads to an elevated role for the Sami Parliaments as the representative bodies for all Sami. As we have seen above, in Canadian law, the State's duty to consult Aboriginal right-bearing communities stems from a constitutional background and is built around the principle of the honour of the Crown. Nevertheless, as Dwight Newman has said, the duty to consult in Canada does not exist in isolation, but is situated within the context of a larger set of international law norms which interact with domestic Canadian law concerning consultation with Aboriginal peoples. ${ }^{88}$ Whether the concept of FCIP in the UNDRIP will evolve in Canadian case law remains, however, to be seen.

As shown in this article, the rationale for the duty to consult Indigenous peoples in a Nordic and Canadian setting is clearly different. In Canada, the duty to consult is part of internal law and developed by courts, in particular the Supreme Court of Canada, as a response to giving effect and meaning to section 35(1) for Aboriginal communities. It moulds the relations between Aboriginal communities and other communities in Canada. In the Nordic States the duty to consult the Sami originates from law outside the domestic legal system. In this sense international legal obligations are foreign law implemented into national law. I cannot help wondering if this aspect is a reason behind the longstanding reluctance of the Nordic States, and especially Sweden, towards formalising and properly applying specific consultation rights for the Sami. It seems much easier to accept laws that have evolved through the national court system, and supreme court rulings on cases have another kind of legitimacy.

With respect to the three Nordic countries, there are remarkable differences to their approaches given the fact that the Sami are one people across all the states. Norway has the most evolved rules on consultation with the Consultation Agreements and Guidelines, while Sweden still lacks specific provisions on consultation with the Sami, although this may change in the near future if the new act is passed. In Finland the duty to consult is restricted to the Sami homeland area.

The Sami Parliament is seen as the key partner in consultation in all three states, but in Norway, other Sami groups and organisations may also have the right to be consulted, depending on the matter at hand. If it concerns natural resource development, affected reindeer herders and other Sami right-holders should be offered consultation. It has been highlighted that opinions may differ among local Sami groups 


\section{Christina Allard}

and the Sami Parliament concerning a plan or resources development, which furthers the need to consult with other Sami groups than the Sami Parliament in order to meet the international duty to consult.

One downside of the duty to consult Indigenous peoples arising from obligations under international law is that in order to become effective it needs to be fully incorporated into national law so that the right can be properly enforced through the domestic court system. This is not the case in Norway at present because the duty is based on political agreements and not legislation. However, it is unlikely that the Nordic States would have developed their own set of national rules on the duty to consult in the manner of Canada without the international laws. One reason is the fact that the Nordic States, in adhering to the civil law system, have weaker constitutions and court systems than Canada; another is that the Nordic States have a long tradition of hearing interests groups and allowing comments on legislative proposals (remiss/høring). International law may also influence or inspire the development of the state's consultation duty in Canada, for instance regarding legislative measures.

Undoubtedly, the duty to consult (and seek consent) is evolving internationally as well as in the Nordic and Canadian contexts. At a minimum, prior to exploration or exploitation of resources attached to traditional territories - or prior to other decisions that may negatively impact on their communities - states need to engage in good faith consultations with the Indigenous people and/or potentially affected Indigenous groups. Such consultation not only encompasses environmental impacts, but also property rights and other rights. Lack of adequate consultation may lead to escalating conflicts resulting in expressions of anger and mistrust. We should remind ourselves that one purpose of consultation "is to respect Indigenous communities rather than to force changes upon them". ${ }^{89}$

\section{Acknowledgments}

This article was originally based on a short paper presented at a Seminar held in Missinipe, Northern Saskatchewan, Canada, June 2015. I wish to extend my warm gratitude to the organizer, International Centre for Northern Governance and Development at University of Saskatchewan, and especially Prof. Greg Poelzer, for the invitation, fruitful discussions and the wonderful time spent together with the other participants at the fish camp. My warm thanks go also to Assoc. Prof. Kaisa Raitio and Dr. Rebecca Lawrence for comments on an earlier draft of this article.

\section{NOTES}

1. S. James Anaya, Indigenous peoples in international law (Oxford: Oxford University Press, 2004), 153-55; Dwight Newman, Michelle Biddulph and Lorelle Binnion, "Arctic Energy Development and Best Practices on Consultation with Indigenous Peoples," Boston University International Law Journal 32 (2014), 450-51; Leena Heinämäki, "Global Context - Arctic Importance: Free, Prior and Informed 


\section{The Rationale for the Duty to Consult Indigenous Peoples}

Consent, a New Paradigm in International Law Related to Indigenous Peoples" in Indigenous Peoples' Governance of Land and Protected Territories in the Arctic, eds. Thora Martina Herrman and Thibault Martin (Cham: Springer, 2016), 210, 237.

2. Special Rapporteur on the situation of human rights and fundamental freedoms of indigenous people, UN Doc. A/HRC/12/34 (15 July, 2009), para. 37.

3. Indigenous $\mathcal{E}$ tribal peoples' rights in practice: A guide to ILO Convention No. 169 (Geneva: International Labour Organization, 2009), 59.

4. Helen Quane, "The UN Declaration on the Rights of Indigenous Peoples: New Directions for SelfDetermination and Participatory Rights?" in Reflections on the UN Declaration on the Rights of Indigenous Peoples, eds. Stephen Allen and Alexandra Xanthaki (Oxford: Hart Publishing, 2011), 263.

5. Heinämäki, "Global Context - Arctic Importance: Free, Prior and Informed Consent”, 239. See e.g. also the opinion of the former UN Special Rapporteur, James Anaya: UN Doc. A/HRC/12/34 (15 July, 2019), paras. $46,48$.

6. Dwight G. Newman, Revisiting the Duty to Consult Aboriginal Peoples (Saskatoon: Purich Publishing Limited, 2014), 172.

7. Heinämäki, “Global Context - Arctic Importance: Free, Prior and Informed Consent”, 224-27; Leena Heinämäki, "The Rapidly Evolving International Status of Indigenous Peoples: The Example of the Sami People in Finland" in Indigenous Rights in Scandinavia - Autonomous Sami Law, eds. Christina Allard and Susann F. Skogvang (Farnham: Ashgate, 2015), 196.

8. Heinämäki, “The Rapidly Evolving International Status of Indigenous Peoples”, 197.

9. Information received from Professor Nigel Bankes, University of Calgary (power point presentation, October 2016), and a synopsis of Canadian case law prepared by the law student Amy Matychuk, University of Calgary.

10. There are a few key cases particularly in Norway and Sweden, see further Christina Allard, "Some Characteristic Features of Scandinavian Laws and their Influence on Sami Matters" in Indigenous Rights in Scandinavia - Autonomous Sami Law, eds. Christina Allard and Susann F. Skogvang (Farnham: Ashgate, 2015), 58-63.

11. cf. Konrad Zweigert and Hein Kötz, Introduction to Comparative Law, $3^{\text {rd }}$ ed. (Oxford: Clarendon Press, 2011), 277.

12. Christina Allard, “The Nordic countries' law on Sámi territorial rights," Arctic Review on Law and Politics 2 (2011).

13. Norwegian Supreme Court: Rt. 2001 s. 1229.

14. The revised text was released in January 2017 and is under consideration in each state. The Sami Parliaments shall endorse the text before the three states may sign and ratify the Convention, see Preamble (last para.) and Article 42.

15. If necessary the state must also consult with other Sami groups, such as reindeer-herding communities and Sami organisations.

16. See further Ulf Mörkenstam, Eva Josefsen and Ragnhild Nilsson, "The Nordic Sámediggis and the limits of Indigenous self-determination," Gáldu Cála - Fournal of Indigenous Peoples Rights 1 (2016).

17. See the Norwegian Constitution, 1814, s. 108; the Finnish Constitution, 1999, s. 17 para. 3.

18. Commission report: NOU 1984:18 Om samenes rettsstilling, 432.

19. See the Instrument of Government, 1974, ch. 1, s. 2, para. 6.

20. In Norwegian: Prosedyrer for konsultasjoner mellom statlige myndigheter og Sametinget. An English translation is available at the Government webpage, accessed 12 April, 2017, https:/www.regjeringen.no/en/ topics/indigenous-peoples-and-minorities/Sami-people/midtspalte/PROCEDURES-FORCONSULTATIONS-BETWEEN-STA/id450743/ .

21. In Norwegian: Avtale mellom Sametinget og Miljøverndepartementet om retningslinjer for verneplan arbeid etter naturvernloven $i$ samiska områder.

22. Commission report: NOU 2007:13 Den nye sameretten, 824, 880.

23. Susann F. Skogvang, Samerett (Oslo: Universitetsforlaget, 2009), 83.

24. Veileder for statlige myndigheters konsultasjoner med sametinget og eventuelle øvrige samiske interesser [Guidelines to the basic Consultation Agreement](Oslo: Arbeids- og inkluderingsdepartementet, 2006), 2.

25. "Procedures for Consultations between State Authorities and the Sami Parliament" [basic Consultation Agreement], article 6; Veileder for statlige myndigheters konsultasjoner [Guidelines to the basic Consultation Agreement], 10. 


\section{Christina Allard}

26. Guidelines to the basic Consultation Agreement, 5 .

27. Basic Consultation Agreement, article 2; Guidelines to the basic Consultation Agreement, 6 .

28. Guidelines to the basic Consultation Agreement, 7 .

29. Ibid., 6 .

30. Basic Consultation Agreement, article 9; Guidelines to the basic Consultation Agreement, 16.

31. Guidelines to the basic Consultation Agreement, 16-7.

32. Basic Consultation Agreement, article 2; Guidelines to the basic Consultation Agreement, 8 .

33. Guidelines to the basic Consultation Agreement, 8.

34. Ibid., 3.

35. NOU 2007:13,1020-1. The report includes a proposal to include a new provision on the duty to consult in the Nature Diversity Act, 2009. See ibid., 1022-3.

36. Guidelines to the basic Consultation Agreement, 18.

37. NOU 2007:13, 54-8, Ch. 17.

38. NOU 2007:13: 874-5.

39. The area is demarcated through the Sami Parliament Act, 1995, s. 4, and roughly comprises the three northernmost municipalities.

40. Finnish Constitution, 1999, s. 121, para. 4.

41. Government bill: RP 264/2014 Regeringens proposition till riksdagen om godkännande av konventionen om ursprungsfolk och stamfolk $i$ självstyrande länder samt med förslag till lagar om sättande $i$ kraft av de bestämmelser $i$ konventionen som hör till området för lagstiftningen och om ändring av lagen om Forststyrelsen. For the process see also Heinämäki, “The Rapidly Evolving International Status of Indigenous Peoples,” 203.

42. Government bill: RP 167/2014 Regeringens proposition till riksdagen med förslag till lagar om ändring av sametingslagen och strafflagen. The reason behind this failure was the disagreement on the definition of who is Sami.

43. RP $167 / 2014,31$.

44. RP 264/2014, 38.

45. See e.g. Tanja Joona, "The Definition of a Sami Person in Finland and its Application" in Indigenous Rights in Scandinavia - Autonomous Sami Law, eds. Christina Allard and Susann F. Skogvang (Farnham: Ashgate, 2015), 165-66.

46. Christina Allard, Renskötselrätt i nordisk belysning (Stockholm, Makadam förlag, 2015), 11, 47-8, 51-2.

47. They need, however, to be heard under the Minerals Act, 2011, s. 38.

48. RP 264/2014, 32 .

49 cf. Government report Ds 2009:40 Vissa samepolitiska frågor.

50. Government report: Ds 2017:43 Konsultation i frågor som rör det samiska folket.

51. Ds 2009:40, 100-1.

52. Ds 2009:40, 103.

53. Ds 2009:40, 42, 100-5.

54. Ds 2017:43, 1, 19, 37.

55. Government bill: Prop. 1992/93:32 Samerna och samisk kultur m.m., 33-5; Rebecca Lawrence and Ulf Mörkenstam, "Självbestämmande genom myndighetsutövning? Sametingets dubbla roller," Statsvetenskaplig Tidskrift 2 (2012).

56. Sami Parliament Act, 1992, ch. 2, s. 1.

57. Instrument of Government, 1974, ch. 7, s. 2, para. 6.

58. Ds 2009:40, 93-4.

59. Peter Johansson, "Samerna - ett ursprungsfolk eller en minoritet? En studie av svensk samepolitik 1986-2005" (PhD diss., University of Gothenburg, 2008).

60. Christina Allard, "Two Sides of the Coin - Rights and Duties. The Interface between Environmental Law and Saami Law Based on a Comparison with Aoteoaroa/New Zealand and Canada" (PhD diss., Luleå University of Technology, 2006), 500-1.

61. Kristina Labba, "Mineral Activities on Sami Reindeer Grazing Land in Sweden," Nordisk Miljörättslig Tidskrift 1 (2014).

62. Allard, "Two Sides of the Coin", 432.

63. Minerals Act, 1991, ch. 4, s. 2, para. 1.

64. cf. Minerals Act, 1991, ch. 4, s. 2, para. 5.

65. Government bill: Prop. 2013/14:159 Bättre information och tydligare ansvar vid mineralprospektering. 


\section{The Rationale for the Duty to Consult Indigenous Peoples}

66. Minerals Act, 1991, ch. 3, ss. 5-5 d.

67. Environmental Code, 1998, ch. 9, s. 6; Regulation on Environmental Permits, 2013, ch. 4.

68. Ulf Mörkenstam, Eva Josefsen and Ragnhild Nilsson, "The Nordic Sámediggis and the limits of Indigenous self-determination," Gáldu Cála - Fournal of Indigenous Peoples Rights 1 (2016), 16, 20.

69. Ibid.

70. See e.g. the last Sápmi report by the Special Rapporteur, UN Doc. A/HRC/33/42/Add.3 (9 August, 2016), paras. 20,30, concerning energy development projects and reindeer husbandry.

71. The Convention for the Protection of Human Rights and Fundamental Freedoms, 1950.

72. The Human Rights Act, 1999.

73. Newman, Duty to Consult, 15, 60, 65.

74. Supreme Court of Canada: R. v. Sparrow, [1990] 3 C.N.L.R. 160, 178.

75. See further Newman, Biddulph and Binnion, "Arctic Energy Development and Best Practices on Consultation", 464-70.

76. Supreme Court of Canada: Haida Nation v. British Columbia (Minister of Forests) 2004 SCC 73; Taku River Tlingit First Nation v. British Columbia (Project Assessment Director), [2004] S.C.C. 74; Mikisew Cree First Nation v. Canada (Minister of Canadian Heritage), [2005] S.C.C. 69.

77. Newman, Duty to Consult, 9, 15-6; Allard, "Two Sides of the Coin", 251-5.

78. Haida Nation v. BC 2004 SCC 73, 76-7, 79.

79. Supreme Court of Canada: Clyde River (Hamlet) v. Petroleum Geo-Services Inc, 2017 SCC 40. See also the associated case Chippewas of the Thames First Nation v. Enbridge Pipelines Inc., 2017 SCC 41 where the NEB's consultation was held to be sufficient.

80. Newman, Duty to Consult, 116-20, 126-7.

81. See the Department of Justice webpage, accessed 8 September, 2017, http://www.justice.gc.ca/eng/csjsjc/principles-principes.html .

82. For meaningful consultation there is a desire for industry involvement, see Newman, Biddulph and Binnion, "Arctic Energy Development and Best Practices on Consultation", 487.

83. Newman, Duty to Consult, 72, 80.

84. Supreme Court of Canada: Rio Tinto Alcan Inc. v. Carrier Sekani Tribal Council, [2010] S.C.C. 43.

85. See Principle 9 that refers to the collaboration with Aboriginal peoples on changes of laws, regulations and policies to fulfill the constitutional promise under Section 35.

86. This approach is seen as part of best practises, see Newman, Biddulph and Binnion, "Arctic Energy Development and Best Practices on Consultation", 480-81,

87. Newman, Duty to Consult, 26.

88. Ibid., 16, 142 .

89. Newman, Biddulph and Binnion, “Arctic Energy Development and Best Practices on Consultation”, 484 . 